Biota Vol. X (3): 31-35, Februari 2005

ISSN 0853-8670

\title{
Pengaruh Pemberian BAP dan NAA terhadap Pertumbuhan Krisan (Chrysanthemum morifolium, Ram.) dalam Kultur Jaringan
}

\author{
The Effect of BAP and NAA on Tissue Culture of Chrysanthemum \\ Yohana Theresia Maria Astuti ${ }^{*}$ dan Neny Andayani ${ }^{1}$ \\ Jurusan Budidaya Pertanian, Fakultas Pertanian, Institut Pertanian Stiper, Yogyakarta \\ Jl. Petung no. 2, Papringan, Yogyakarta. \\ e-mail:astuti_maria2000@yahoo.com,astuti_maria@telkom.net*Penulis untuk korespondensi
}

\begin{abstract}
The objective of this study was to evaluate the effect of combination benzyl amino purine (BAP) and naphtalene acetid acid (NAA) on tissue culture of Chrysanthemum. The experiment was conducted at The Tissue Culture Laboratory, Agriculture Faculty, Stiper Agriculture Institute. The Completely Randomized Design was applied in this experiment, consisting of two factors; those were BAP and NAA application. Each factor consisted of four treatments. Each combination of treatment was carried out with nine replications. The conclusion from this study were: Application of higher BAP and NAA concentration increased budding of explant, whereas application of higher NAA than BAP concentration increased the growth of bud and leaf number, also increased rooting of explant.
\end{abstract}

Key words: benzyl amino purine (BAP), naphtalene acetic acid (NAA), Chrysanthemum, in vitro

Diterima: 04 Februari 2004, disetujui: 31 Mei 2004

\section{Pendahuluan}

Krisan (Chrysanthemum morifolium, Ram.) merupakan salah satu bunga yang banyak diusahakan oleh petani bunga. Permintaan bunga krisan berada pada urutan teratas dibandingkan dengan jenis bunga potong lainnya (Supari, 1999). Dalam pengembangan budidaya krisan, kesulitan mendasar adalah ketersediaan bibit yang berkualitas tinggi. Krisan hibrida merupakan krisan yang berkualitas tinggi, namun benih krisan hibrida tidak dapat langsung dibudidayakan di lapangan. Kesulitan perbanyakan bibit secara besar-besaran dapat dipecahkan dengan penanaman secara in vitro (Gunawan, 1995; Suryowinoto, 1996). Salah satu persyaratan keberhasilan kultur jaringan adalah pemilihan media yang dipakai, baik komposisi maupun jumlahnya. Apabila media yang dipakai sesuai, jaringan yang ditanam akan berkembang dan membentuk kalus, akar, atau tunas (Dodds \& Robert, 1982). Dalam kultur jaringan, dua golongan zat pengatur tumbuh yang sangat penting adalah sitokinin dan auksin. Interaksi dan perimbangan antara zat pengatur tumbuh yang diberikan dalam media dan yang diproduksi oleh sel secara endogen menentukan arah perkembangan suatu kultur sehingga mempengaruhi proses-proses pertumbuhan dan morfogenesis. Salah satu jenis sitokinin sintetis adalah benzyl amino purine (BAP) atau benzyl adenine (BA). Sedangkan naphtalene acetic acid (NAA) merupakan zat pengatur tumbuh dari golongan auksin (George \& Sherington, 1984; Wattimena, 1991).

Prahardini \& Sudaryono (1992) menyimpulkan dalam penelitian pada kultur pepaya bahwa pemberian NAA optimum pada inisiasi tunas majemuk sebesar $0,2 \mathrm{mgl}^{-1}$ dan BAP $0,3 \mathrm{mgl}^{-1}$, sedangkan perakaran terbaik 
ditemukan pada komposisi $0,2 \mathrm{mgl}^{-1} \mathrm{NAA}$ dan $0,4 \mathrm{mgl}^{-1}$ BAP. Simatupang (1993) dalam kultur asparagus menemukan bahwa pada pemberian NAA $1 \mathrm{mgl}^{-1}$ dan kinetin $0,3 \mathrm{mgl}^{-1}$ menghasilkan pertumbuhan tunas terbaik. Guohua (1998) dalam penelitiannya mengenai embriogenesis Manihot esculenta, Crantz. mengemukakan bahwa organogenesis batang dipacu oleh BAP dan NAA. Penelitian mengenai embrio somatik Geranium oleh Madakadze \& Senaratna (2000) menemukan kombinasi BAP dan NAA $0,1 \mathrm{mgl}^{-1}$ akan memacu pembentukan protein tertentu yang diperlukan dalam embriogenesis.

Penggunaan BAP dan NAA pada media kultur jaringan untuk tanaman krisan sudah pernah dilakukan oleh Wambugu dan Rangan (1981) yang menemukan konsentrasi optimum untuk pembentukan pucuk terminal adalah 0,2 $\mathrm{mgl}^{-1}$ BAP, dan konsentrasi optimum untuk perakaran tunas digunakan NAA $0,2 \mathrm{mgl}^{-1}$. Staba et al., (1984) menemukan konsentrasi optimum untuk proliferasi tunas in vitro eksplan krisan adalah $20 \mathrm{mgl}^{-1}$ kinetin. Penelitian terhadap kultur krisan sebagai salah satu tanaman penghasil pestisida nabati dilakukan oleh Ermayanti et al., (1999) yang memberikan hasil konsentrasi zat pengatur tumbuh optimum untuk pertumbuhan tunas krisan secara in vitro adalah kombinasi 0,02 $\mathrm{mgl}^{-1}$ NAA dan $2 \mathrm{mgl}^{-1}$ kinetin.

Penelitian ini bertujuan untuk mengetahui pengaruh pemberian BAP dan NAA dalam perbanyakan tanaman krisan secara in vitro. Hasil penelitian ini diharapkan akan mampu memberikan sumbangan pemikiran dalam pemecahan masalah pembangunan, mengenai cara-cara memperoleh bibit unggul dan seragam secara in vitro untuk tanaman krisan.

\section{Metode Penelitian}

Benih krisan hibrida dikecambahkan pada media Murashige \& Skoog (MS) tanpa penambahan zat pengatur tumbuh. Setelah planlet berumur satu bulan, pucuk dipotong dan ditanam pada media MS dengan penambahan NAA 0,02 $\mathrm{mgl}^{-1}$ dan BAP yang terdiri dari 4 aras konsentrasi BAP sebagai perlakuan, yaitu 0,0 $\mathrm{mgl}^{-1}$ (B0), 0,1 $\mathrm{mgl}^{-1}$ (B1), 0,2 $\mathrm{mgl}^{-1}$ (B2), dan $0,3 \mathrm{mgl}^{-1}$ (B3). Setelah planlet berumur satu bulan, setiap plantlet dipindahkan pada media MS dengan penambahan NAA, yang terdiri dari 4 aras konsentrasi NAA sebagai perlakuan, yaitu $0,0 \mathrm{mgl}^{-1}$ (N0), $0,1 \mathrm{mgl}^{-1}$ (N1), 0,2 mgl ${ }^{-1}$ (N2), dan $0,3 \mathrm{mgl}^{-1}(\mathrm{~N} 3)$. Dengan demikian, diperoleh kombinasi perlakuan 4 aras BAP X 4 aras NAA, yaitu:

B0N0, B0N1, B0N2, B0N3

B1N0, B1N1, B1N2, B1N3

B2N0, B2N1, B2N2, B2N3

B3N0, B3N1, B3N2, B3N3

Setiap kombinasi perlakuan dengan sembilan ulangan.

Setelah planlet berumur satu bulan, dilakukan pengamatan terhadap jumlah tunas, tinggi tunas, jumlah daun, jumlah akar, panjang akar dan berat segar planlet. Hasil penelitian dianalisis dengan menggunakan analisis varian pada jenjang nyata 5\%. Untuk mengetahui perbedaan antar perlakuan, dilakukan uji jarak berganda Duncan pada jenjang nyata 5\%.

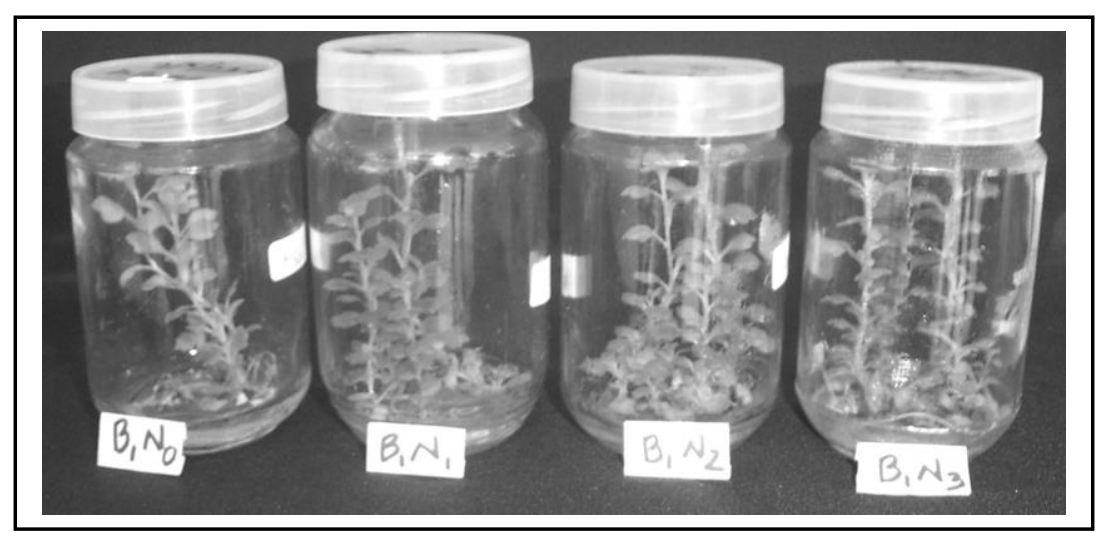

Gambar 1. Planlet Krisan pada Perlakuan B1N0, B1N1, B1N2, B1N3 


\section{Hasil dan Pembahasan}

Hasil analisis varian memperlihatkan ada interaksi nyata antara pemberian BAP dan NAA dalam mempengaruhi pertumbuhan eksplan krisan. Hal ini berarti kombinasi BAP dan NAA secara bersama-sama mempengaruhi pertumbuhan eksplan krisan.

Pada hasil analisis parameter pertumbuhan plantlet, perlakuan pemberian BAP menunjukkan jumlah tunas yang lebih banyak dibandingkan perlakuan tanpa BAP (Tabel 1). Hal in menunjukkan bahwa BAP, yang termasuk golongan sitokinin, dapat mendorong proliferasi tunas. Penelitian ini menggunakan eksplan pucuk. Pada penanaman konvensional, dari satu pucuk akan tetap tumbuh satu tunas saja. Dengan pemberian sitokinin, dari satu pucuk dapat tumbuh lebih dari satu tunas (proliferasi tunas). Hal ini sesuai dengan pendapat Wattimena (1991), Rubbyanto (1998) serta Holland (1997) bahwa peran sitokinin adalah mendorong pertunasan serta pemecahan dormansi eksplan. Jumlah tunas yang terbentuk tersebut terdapat pada eksplan yang ditumbuhkan pada media dengan penambahan BAP, dengan maupun tanpa NAA. Dalam kultur jaringan, pembentukan tunas dipacu oleh adanya zat pengatur tumbuh dari golongan sitokinin yang dikombinasikan dengan auksin dalam konsentrasi kecil. Eksplan dari tunas krisan sudah mengandung auksin endogen yang cukup untuk pembentukan tunas.

Hasil analisis tinggi tunas pada kombinasi perlakuan BAP $0,1 \mathrm{mgl}^{-1}$ dan NAA $0,2 \mathrm{mgl}^{-1}$ (B1N2) serta BAP $0,1 \mathrm{mgl}^{-1}$ dan NAA $0,3 \mathrm{mgl}^{-1}$ (B1N3) lebih tinggi daripada tunas pada perlakuan lainnya (Tabel 1). Hal ini menunjukkan bahwa BAP, yang termasuk golongan sitokinin yang dikombinasikan dengan NAA pada konsentrasi yang lebih tinggi dari BAP dapat meningkatkan pertumbuhan tunas. Penelitian ini menggunakan eksplan pucuk yang mengandung auksin endogen. Hal ini menunjukkan bahwa pertambahan tinggi tunas lebih dipengaruhi oleh NAA (yang termasuk golongan auksin) daripada BAP (yang termasuk golongan sitokinin). Pertambahan tinggi tunas lebih banyak dipengaruhi oleh pemanjangan serta pembelahan sel pada meristem pucuk. Proses tersebut dipengaruhi oleh hormon auksin dan sitokinin, dengan konsentrasi auksin yang lebih tinggi. Hal ini sesuai dengan pendapat Gunawan
(1987) bahwa auksin mempunyai peran dalam proses pemanjangan serta pembelahan sel.

Pembentukan daun merupakan bagian dari pertumbuhan tunas. Pada hasil analisis, jumlah daun pada kombinasi perlakuan BAP $0,1 \mathrm{mgl}^{-1}$ dan NAA 0,2 $\mathrm{mgl}^{-1}$ (B1N2) serta BAP 0,1 $\mathrm{mgl}^{-1}$ dan NAA $0,3 \mathrm{mgl}^{-1}$ (B1N3) lebih banyak daripada jumlah daun pada planlet yang ditumbuhkan pada perlakuan lain (Tabel 1) Jumlah daun yang terbentuk dipengaruhi oleh pemberian auksin dan sitokinin yang berupa NAA dan BAP, dengan konsentrasi auksin yang lebih tinggi, seperti halnya pada pertambahan tinggi tunas. Selain itu, pembentukan daun juga dipengaruhi oleh pemberian nitrogen, mengingat di dalam daun banyak terdapat sel-sel yang mengandung kloroplas. Pembentukan daun dalam kultur jaringan membutuhkan sitokinin dan auksin dalam perbandingan konsentrasi tertentu. Meskipun tunas mempunyai auksin endogen, tetapi pemberian auksin eksogen masih mampu berpengaruh terhadap penambahan jumlah daun.

Hasil analisis jumlah akar pada kombinasi perlakuan BAP $0,0 \mathrm{mgl}^{-1}$ dan NAA $0,2 \mathrm{mgl}^{-1}$ (B0N2), BAP 0,1 $\mathrm{mgl}^{-1}$ dan NAA $0,2 \mathrm{mgl}^{-1}$ (B1N2), BAP 0,0 $\mathrm{mgl}^{-1}$ dan NAA $0,3 \mathrm{mgl}^{-1}$ (B0N3) serta BAP 0,1 $\mathrm{mgl}^{-1}$ dan NAA $0,3 \mathrm{mgl}^{-1}$ (B1N3) lebih banyak daripada jumlah akar pada kombinasi perlakuan lainnya (tabel 1). Terlihat dari hasil analisis tersebut, pemberian NAA yang lebih tinggi daripada BAP memacu pembentukan perakaran eksplan. Hal ini sesuai dengan pendapat Holland (1997) dan Wattimena (1991) bahwa pada kultur jaringan, penggunaan auksin berperan dalam pembentukan akar, sedangkan sitokinin dalam jumlah sedikit membantu pembentukan/ morfogenesis akar.

Hasil analisis pada Tabel 1 terlihat panjang akar tidak ada beda nyata pada kombinasi perlakuan BAP $0,0 \mathrm{mgl}^{-1}$ dan NAA $0,0 \mathrm{mgl}^{-1}, 0,1$ $\mathrm{mgl}^{-1}, 0,2 \mathrm{mgl}^{-1}$, serta $0,3 \mathrm{mgl}^{-1}$ (BON0, BON1, B0N2, B0N3); BAP 0,1 $\mathrm{mgl}^{-1}$ dan NAA $0,2 \mathrm{mgl}^{-}$ 1 , BAP $0,1 \mathrm{mgl}^{-1}$ dan NAA $0,3 \mathrm{mgl}^{-1}$ (B1N2, B1N3); BAP 0,2 $\mathrm{mgl}^{-1}$ dan NAA $0,0 \mathrm{mgl}^{-1}$ (B2N0); BAP $0,3 \mathrm{mgl}^{-1}$ dan NAA $0,0 \mathrm{mgl}^{-1}$, BAP 0,3 $\mathrm{mgl}^{-1}$ dan NAA $0,3 \mathrm{mgl}^{-1}$ (B3N0, B3N3). Hal ini menunjukkan kombinasi BAP dan NAA pada berbagai perbandingan konsentrasi berpengaruh terhadap pertambahan panjang akar. Pertambahan panjang akar dipengaruhi oleh pemanjangan serta pembelahan sel pada meristem ujung akar. Proses tersebut dipengaruhi oleh kombinasi hormon auksin dan sitokinin yang 
berperan dalam proses pemanjangan dan pembelahan sel (Gunawan, 1987). Penelitian ini menggunakan eksplan pucuk yang mensintesis auksin endogen, sedangkan ujung akar mensintesis sitokinin. Kombinasi kedua hormon tersebut memacu pemanjangan akar. Pemberian auksin dan sitokinin dalam perbandingan konsentrasi tertentu mampu meningkatkan pemanjangan akar.

Pada hasil analisis berat segar planlet krisan terlihat tidak ada beda nyata pada berbagai kombinasi perlakuan BAP dan NAA (tabel 1). Berat segar planlet meningkat pada pemberian BAP konsentrasi tinggi dengan maupun tanpa NAA serta NAA konsentrasi tinggi dengan maupun tanpa BAP. Berat segar tanaman merupakan tolok ukur pertumbuhan tanaman secara keseluruhan. Dari uraian di atas terlihat bahwa pertumbuhan planlet didukung oleh berbagai parameter, yaitu jumlah tunas, tinggi tunas, jumlah daun, jumlah akar, serta panjang akar. Pada setiap parameter tersebut, terdapat peningkatan pertumbuhan pada nisbah konsentrasi BAP dan NAA tertentu. Pertumbuhan organ tertentu pada planlet akan memberikan kontribusi pada berat segar planlet krisan. Dengan demikian diperoleh berat segar planlet terbaik pada kombinasi perlakuan BAP konsentrasi tinggi dengan maupun tanpa NAA serta kombinasi perlakuan NAA konsentrasi tinggi dengan maupun tanpa BAP. Hal ini sesuai dengan pendapat Guohua (1998) bahwa sitokinin dan auksin mempunyai peran dalam organogenesis pucuk tanaman secara in vitro.

Tabel 1. Pengaruh pemberian BAP dan NAA dalam medium MS terhadap pertumbuhan Planlet Krisan

\begin{tabular}{|c|c|c|c|c|c|}
\hline & $\begin{array}{l}\mathrm{NAA} \\
\left(\mathrm{mgl}^{-1}\right)\end{array}$ & $\begin{array}{l}0,0 \\
\text { B0 } \\
\end{array}$ & $\begin{array}{l}\text { BAP (m } \\
0,1 \\
\text { B1 } \\
\end{array}$ & $\begin{array}{l}0,2 \\
\text { B2 } \\
\end{array}$ & $\begin{array}{l}0,3 \\
\text { B3 } \\
\end{array}$ \\
\hline \multicolumn{6}{|c|}{ Jumlah Tunas: } \\
\hline NO & 0,0 & $1,50_{\mathrm{bc}}$ & $2,25_{\mathrm{abc}}$ & $3,00_{\mathrm{ab}}$ & $1,71_{\mathrm{abc}}$ \\
\hline $\mathrm{N} 1$ & 0,1 & $1,50_{\mathrm{bc}}$ & $1,83_{\mathrm{abc}}$ & $2,33_{\mathrm{abc}}$ & $3,25_{\mathrm{a}}$ \\
\hline $\mathrm{N} 2$ & 0,2 & $1,50_{\mathrm{bc}}$ & $2,00_{\mathrm{abc}}$ & $3,00_{\mathrm{ab}}$ & $2,22_{\mathrm{abc}}$ \\
\hline N3 & 0,3 & $2,57_{\mathrm{abc}}$ & $2,00_{\mathrm{abc}}$ & $1,40_{\mathrm{c}}$ & $2,83_{\mathrm{abc}}$ \\
\hline \multicolumn{6}{|c|}{ Tinggi Tunas (dalam $\mathrm{cm})$ : } \\
\hline No & 0,0 & $6,60_{\mathrm{cd}}$ & $2,85_{\mathrm{cd}}$ & $8,00_{\mathrm{bc}}$ & $8,33_{\mathrm{bc}}$ \\
\hline $\mathrm{N} 1$ & 0,1 & $4,40_{\mathrm{cd}}$ & $1,08_{d}$ & $4,57_{\mathrm{cd}}$ & $4,47_{\mathrm{cd}}$ \\
\hline $\mathrm{N} 2$ & 0,2 & $6,95_{\mathrm{cd}}$ & $13,27_{\mathrm{ab}}$ & $4,13_{\mathrm{cd}}$ & $5,96_{\mathrm{cd}}$ \\
\hline N3 & 0,3 & $8,21_{\mathrm{bc}}$ & $16,28_{\mathrm{a}}$ & $2,82_{\mathrm{cd}}$ & $9,27_{\mathrm{bc}}$ \\
\hline \multicolumn{6}{|c|}{ Jumlah Daun: } \\
\hline No & 0,0 & $21,75_{\mathrm{bc}}$ & $15,25_{\mathrm{bc}}$ & $17,33_{\mathrm{bc}}$ & $21,71_{\mathrm{bc}}$ \\
\hline $\mathrm{N} 1$ & 0,1 & $15,50_{\mathrm{bc}}$ & $7,83_{\mathrm{c}}$ & $18,33_{\mathrm{bc}}$ & $16,12_{\mathrm{bc}}$ \\
\hline $\mathrm{N} 2$ & 0,2 & $23,50_{\mathrm{b}}$ & $41,33_{\mathrm{a}}$ & $20,00_{\mathrm{bc}}$ & $17,77_{\mathrm{bc}}$ \\
\hline $\mathrm{N} 3$ & 0,3 & $26,30_{b}$ & $38,80_{\mathrm{a}}$ & $16,80_{\mathrm{bc}}$ & $21,83_{\mathrm{bc}}$ \\
\hline \multicolumn{6}{|c|}{ Jumlah Akar: } \\
\hline No & 0,0 & $6,75_{\text {bcdef }}$ & $0,75_{\mathrm{f}}$ & $9,00_{\mathrm{abcd}}$ & $6,85_{\text {bcdef }}$ \\
\hline $\mathrm{N} 1$ & 0,1 & $4,50_{\text {cdef }}$ & $1,50_{\mathrm{ef}}$ & $2,66_{\text {def }}$ & $7,37_{\text {bcdef }}$ \\
\hline $\mathrm{N} 2$ & 0,2 & $8,50_{\text {abcde }}$ & $14,30_{\mathrm{a}}$ & $7,00_{\text {bcdef }}$ & $3,77_{\text {cdef }}$ \\
\hline $\mathrm{N} 3$ & 0,3 & $10,85_{\mathrm{abc}}$ & $13,40_{\mathrm{ab}}$ & $2,80_{\mathrm{def}}$ & $6,16_{\text {cdef }}$ \\
\hline \multicolumn{6}{|c|}{ Panjang Akar (dalam $\mathrm{cm}$ ): } \\
\hline NO & 0,0 & $16,83_{\mathrm{abcd}}$ & $1,20_{\mathrm{ef}}$ & $17,27_{\mathrm{abc}}$ & $16,71_{\mathrm{abc}}$ \\
\hline $\mathrm{N} 1$ & 0,1 & $13,90_{\mathrm{abcd}}$ & $0,57_{\mathrm{f}}$ & $7,97_{\text {cdef }}$ & $10,75_{\mathrm{cde}}$ \\
\hline $\mathrm{N} 2$ & 0,2 & $18,35_{\mathrm{abc}}$ & $22,13_{\mathrm{ab}}$ & $11,90_{\text {bcd }}$ & $9,08_{\text {cdef }}$ \\
\hline N3 & 0,3 & $15,46_{\mathrm{abc}}$ & $23,62 \mathrm{a}$ & $4,74_{\text {def }}$ & $16,90_{\mathrm{abc}}$ \\
\hline \multicolumn{6}{|c|}{ Berat Segar Planlet (dalam g): } \\
\hline No & 0,0 & $0,61_{\text {bcd }}$ & $0,28_{\mathrm{cd}}$ & $1,66_{\mathrm{a}}$ & $1,27_{\mathrm{ab}}$ \\
\hline N1 & 0,1 & $0,62_{\mathrm{bcd}}$ & $0,14_{d}$ & $0,61_{\mathrm{bcd}}$ & $0,96_{\mathrm{abcd}}$ \\
\hline $\mathrm{N} 2$ & 0,2 & $1,01_{\mathrm{abcd}}$ & $1,72_{\mathrm{a}}$ & $0,98_{\text {abcd }}$ & $1,00_{\mathrm{abcd}}$ \\
\hline $\mathrm{N} 3$ & 0,3 & $1,22_{\mathrm{ab}}$ & $1,74_{\mathrm{a}}$ & $0,36_{\mathrm{bcd}}$ & $1,16_{\mathrm{abc}}$ \\
\hline
\end{tabular}




\section{Kesimpulan}

Berdasarkan hasil penelitian dan pembahasan dapat diambil kesimpulan pemberian BAP yang lebih tinggi daripada NAA dapat mendorong pembentukan tunas. Kombinasi NAA dengan konsentrasi yang lebih tinggi daripada konsentrasi BAP dapat meningkatkan pertumbuhan tunas, jumlah daun serta pembentukan perakaran eksplan.

\section{Daftar Pustaka}

Dodds, J.H. and Roberts, L.W. 1982. Experiments in Plant Tissue Culture. Cambridge University Press. Sidney.

Ermayanti, T.M., Sulistyowati, Y., Sari, L., Siregar, E.M.R. and Simanjuntak, P. 1999. Kultu Jaringan Beberapa Tanaman Penghasil Pestisida Nabati. J.Biosains 4 (1): 11-20.

George, E.F. and Sherrington, P.D. 1984. Plant Propagation by Tissue Culture. Exegetics Ltd. London.

Gunawan, 1995. Kultur Jaringan Hortikultura. Gramedia. Jakarta.

Gunawan, 1987. Teknik Kultur Jaringan Laboratorium Kultur Jaringan Tanaman. Pusat Antar Universitas (PAU) Bioteknologi Institut Pertanian Bogor. Bogor.

Guohua, M. 1998. Effects of Cytokinins and Auxins on Cassava Shoot Organogenesis. Plant Cell, Tissue and Organ Culture 54: 1-7.

Holland, M.A. 1997. Occam's Razor Applied to Hormonology: Are Cytokinins Produced by Plants. Plant Physiology (1997) 115: 865868.
Madakadze, R.M. and Senaratna, T. 2000. Effect of Growth Regulators on Maturation of Geranium (Pelargonium x hortorum) Somatic Embryos. Plant Growth Regulation 30 : 5560.

Prahardini, P.E.R. dan Sudaryono, T. 1992. Pengaruh Kombinasi Asam Naftalen Asetat dan Benzil Adenin terhadap Kultur Pepaya Kultivar Dampit secara In Vitro. Jurnal Hortikultura 2(4): 6-12.

Rubbyanto. 1998. Pengaruh IAA dan BAP terhadap Inisiasi dan Multiplikasi Tunas Pisang Tanduk secara In Vitro. Balithorti. Solok.

Simatupang, S. 1993. Observasi Perbanyakan Asparagus (Asparagus officinalis L.) Melalui Kultur In Vitro. Buletin Penelitian Hortikultura 15 (1) : 58-65.

Staba, E.J., Nygaard, B.G. and Zito, S.W. 1984. Light Effects on Pyrethrum Shoot Cultures. Plant Cell, Tissue and Organ Culture 3 : 211-214.

Supari, D. 1999. Tuntunan Membangun Agribisnis. Gramedia. Jakarta.

Suryowinoto, M. 1996. Pemuliaan Tanaman secara In Vitro. Kanisius. Yogyakarta.

Wambugu, E.M. and Rangan, T.S. 1981. In Vitro Clonal Multiplication of Pyrethrum (Chrysantemum cinerariaefolium) by Micropropagation. Plant Sci. Lett. 22 : 219 - 226.

Wattimena, 1991. Kultur Jaringan Tanaman Pembiakan Mikro dan Manipulasi Genetika pada Beberapa Tanaman Budidaya. Direktorat Pembinaan Penelitian dan Pengabdian pada Masyarakat. Direktorat Jendral Pendidikan. Departemen Pendidikan dan Kebudayaan. 72 halaman. 